Bài báo khoa học

\title{
Nghiên cứu đa dạng sinh học các hệ sinh thái đất ngập nước ven biển Đông Bắc Việt Nam
}

\author{
Nguyễn Mạnh Hà ${ }^{1}$, Vũ Anh Tài ${ }^{*}$, Trần Thị Thúy Vân ${ }^{1}$, Phạm Hoàng Hải ${ }^{1}$, Dương \\ Thị Hồng Yến ${ }^{1}$, Nguyễn Thu Nhung ${ }^{1}$, Hoàng Bắc ${ }^{1}$, Nguyễn Văn Hồng ${ }^{1}$, Đố Ngọc \\ Thực ${ }^{2}$ \\ ${ }^{1}$ Viện Địa lý, Viện Hàn lâm Khoa học và Công nghệ Việt Nam; \\ haig2007@gmail.com; tranthithuyvan@ig.vast.vn; phhoanghai@yahoo.com; \\ duongthihongyen@gmail.com; nthunhung@gmail.com; hoanhbaok2@yahoo.com; \\ nguyenhong.ig@gmail.com \\ ${ }^{2}$ Viện Địa chất và Địa vật lý biển, Viện Hàn lâm Khoa học và Công nghệ Việt Nam; \\ dothuc.vn@gmail.com
}

*Tác giả liên hệ: vatai@ig.vast.vn; Tel.: +84-983353711

Ban Biên tập nhận bài: 8/10/2021; Ngày phản biện xong: 24/11/2021; Ngày đăng bài: $25 / 2 / 2022$

Tóm tắt: Các kết quả điều tra thực địa và nghiên cứu về đa dạng sinh học của các hệ sinh thái đất ngập nước khu vực ven biển Đông Bắc Việt Nam đã được phân tích, đánh giá với 4 sinh cảnh chính: rừng ngập mặn, vùng cửa song, thảm cỏ biển và trảng cỏ ngập nước. Diễn thế sinh thái của các quần xã thực vật ngập mặn đã được xác định bắt đầu từ các quần xã tiên phong Mắm trắng, Sú cong phân bố thành các quần thể đơn loài ở ngoài cùng trên nền bùn lỏng, vào sâu hơn có Trang, Vẹt dù mọc xen nhau, vùng trung tâm có Đước vòi, ở những triền đất cao hơn Bần chua. Hệ sinh thái có mức độ đa dạng nhất là Rừng ngập mặn 1379 loài, cửa sông 1024 loài, thảm cỏ biển 976 loài, trảng cỏ ngập nước chỉ có 433 loài. Các loài quý hiếm được xác định với 26 loài theo Sách đỏ Việt Nam (2007) và 17 loài theo IUCN (2020). Kết quả nghiên cứu cũng chỉ ra rằng các hệ sinh thái vùng ven biển Đông Bắc vẫn đang trong quá trình diễn thế và chưa đạt trạng thái đỉnh cực, vì vậy, cần phải có các kế hoạch cụ thể để bảo tồn và sử dụng hợp lý các nguồn lợi thủy sản ở từng sinh cảnh nói riêng và toàn khu vực ven biển Đông Bắc nói chung.

Từ khóa: Hệ sinh thái; Đa dạng sinh học, Đất ngập nước; Rừng ngập mặn; Ven biển đông bắc.

\section{Mở đầu}

Hệ sinh thái (HST) đất ngập nước (ĐNN) luôn được coi là một trong những HST rất nhạy cảm và có nhiều giá trị đối với đời sống con người nói riêng và đóng vai trò quan trọng trong đa dạng sinh vật của sinh giới nói chung. Nghiên cứu về đa dạng sinh học (ĐDSH) các HST ĐNN có nhiều công trình công bố kết quả nghiên cứu liên quan đến hệ sinh thái rừng ngập mặn đã được tổng hợp, thống kê và đăng tải trong 17 tuyển tập các báo cáo tại Hội thảo của các dự án thuộc khu vực Châu Á-Thái Bình Dương 1. Trong đó có một số công trình công bố có liên quan đến các lĩnh vực: cấu trúc quần xã và khu hệ hệ động thực vật và các thảm thực vật phân bố trong vùng RNM". Tại hội thảo khoa học toàn quốc về hệ sinh thái RNM lần thứ 1 được tổ chức tại Hà Nội năm 1984 đã đánh dấu một bước tiến bộ cùng sự quan tâm đặc biệt của các nhà khoa học nghiên cứu trong lĩnh vực rừng ngập mặn. Các báo cáo đã tập trung đánh giá, phân tích nhiều lĩnh vực trong đó có mô tả một số đặc điểm của 
các khu hệ động thực vật trong HST RNM. Trong bộ chuyên khảo "Biển Đông" 2 phản ánh được khá đầy đủ các kết quả chủ yếu của hoạt động điều tra nghiên cứu biển nước ta trong các giai đoạn tính tới năm 2000, tuy nhiên, ở phần này, các dữ liệu về khu vực nghiên cứu còn khá hạn chế. Đề tài Nghiên cứu các hệ sinh thái dải ven biển Việt Nam, đề xuất phương hướng sử dụng hợp lý và bảo vệ nguồn lợi và môi trường 2 đã thực hiện đánh giá tiềm năng nguồn lợi dải ven biển, hiện trạng sử dụng các hệ sinh thái, trong đó chú trọng đến các nguồn lợi hải sản vùng triều cửa song, đưa ra một số kết quả nghiên cứu phân tích về các HST và ĐDSH. Dự án Thành lập Khu bảo tồn đất ngập nước Đồng Rui-Tiên Yên (Quảng Ninh) do Sở Tài nguyên và Môi trường tỉnh Quảng Ninh thực hiện năm 20183 đã trình bày chi tiết về nhiều lĩnh vực trong đó có ĐDSH, xác định 34 loài loài quý hiếm theo IUCN (2016), 22 loài theo sách đỏ Việt Nam (2007) và 12 loài xét theo nghị định 32/2006/ND-CP, có 1 loài côn trùng và 3 loài thực vật được xếp vào diện "phân bố hẹp" hoặc mang tính đặc hữu cácvùng ĐNN khu vực xã Đồng Rui-Tiên Yên và vùng phụ cận. Cũng có những công trình thực hiện mang tính khái quát về đặc điểm tự nhiên của vùng biển Đông Bắc 4 và một số công trình nghiên cứu về ĐDSH ĐNN của một khu vực cụ thể ở Quảng Ninh-Hải Phòng 5-6 nhưng chưa có công trình nghiên cứu cho toàn bộ khu vực và đồng thời thành lập được bản đồ các HST ĐNN được xử với các thông tin cập nhật từ ảnh viễn thám.

Nghiên cứu về ĐDSH ĐNN nhất là trong bối cảnh chịu tác động của biến đổi khí hậu và nước biển dâng cũng như sự phát triển nhanh, mạnh của các khu đô thị, các khu sản xuất công nghiệp, chăn nuôi công nghiệp ven biển có vai trò rất quan trọng để quản lý tài nguyên thiên nhiên trong định hướng phát triển bền vững và sử dụng hợp lý tài nguyên thủy hải sản của các địa phương. Đó là cơ sở để vừa phát triển hợp lý nguồn lợi thủy sản vừa bảo tồn, bảo vệ các nguồn gen độc đáo, quý hiếm của HST ĐNN và qua đó là bảo vệ chính cuộc sống của chúng ta. Vùng ven biển Đông Bắc Việt Nam vốn rất đa dạng và phức tạp với sự đan xen của nhiều cửa sông, vũng vịnh tạo nên một không gian rất khác biệt với phần còn lại trên toàn bộ tuyến ven biển Việt Nam. Mặc dù vậy, bởi các tác động thường xuyên của con người như giao thông thủy, chặt phá rừng, đào ao nuôi thủy hải sản, xây dựng hạ tầng công trình khu công nghiệp ... cũng như những hệ lụy từ biến đồi khí hậu và nước biển dâng, các HST ĐNN ven biển Đông Bắc vì thế chưa thể đạt được trạng thái đỉnh cực (climax), tức là vẫn đang trong quá trình phát triển, diễn thế sinh thái. ĐNN ven biển Đông Bắc còn là môi trường phát triển kinh tế xã hội, phát triển ngư nghiệp, nông nghiệp rất quan trọng của cả Hải Phòng và Quảng Ninh, hai địa phương đang có tốc độ phát triển kinh tế xã hội và ổn định môi trường rất cao của cả nước và trong đó, HST ĐNN dưới tác động của thủy triều có sự đa dạng lớn nhưng cũng rất nhạy cảm. Vì thế việc hiểu biết rõ về các giá trị về ĐDSH và đánh giá được mức độ đa dạng của các HST thông qua giá trị bảo tồn của những loài quý hiếm, nguy cấp theo các thang đánh giá của IUCN (2020) và Sách đỏ Việt Nam (2007) sẽ hỗ trợ tốt hơn cho công tác bảo vệ tài nguyên thiên nhiên được tốt hơn, giúp HST đạt được mức độ phát triển ổn định hơn.

\section{2. Đối tượng và Phương pháp nghiên cứu}

\section{1. Đối tượng nghiên cúu}

Đối tượng nghiên cứu bao gồm các hệ sinh thái, các thảm thực vật và các loài phân bố ở các sinh cảnh bán ngập nước khu vực ven biển Đông Bắc Việt Nam (Hình 1).

\subsection{Phưong pháp nghiên cúu}

- Phương pháp kế thừa và tổng hợp tài liệu: kế thừa các kết quả nghiên cứu trước đây do các cơ quan, tồ chức, đơn vị và cá nhân các nhà khoa học đã thực hiện liên quan đến đa dạng sinh học của các HST ĐNN, tập trung vào đặc điểm, phân bố và thành phần loài của các HST, khu hệ động thực vật thủy sinh, ngập nước ở các khu vực ven biển Đông Bắc. 


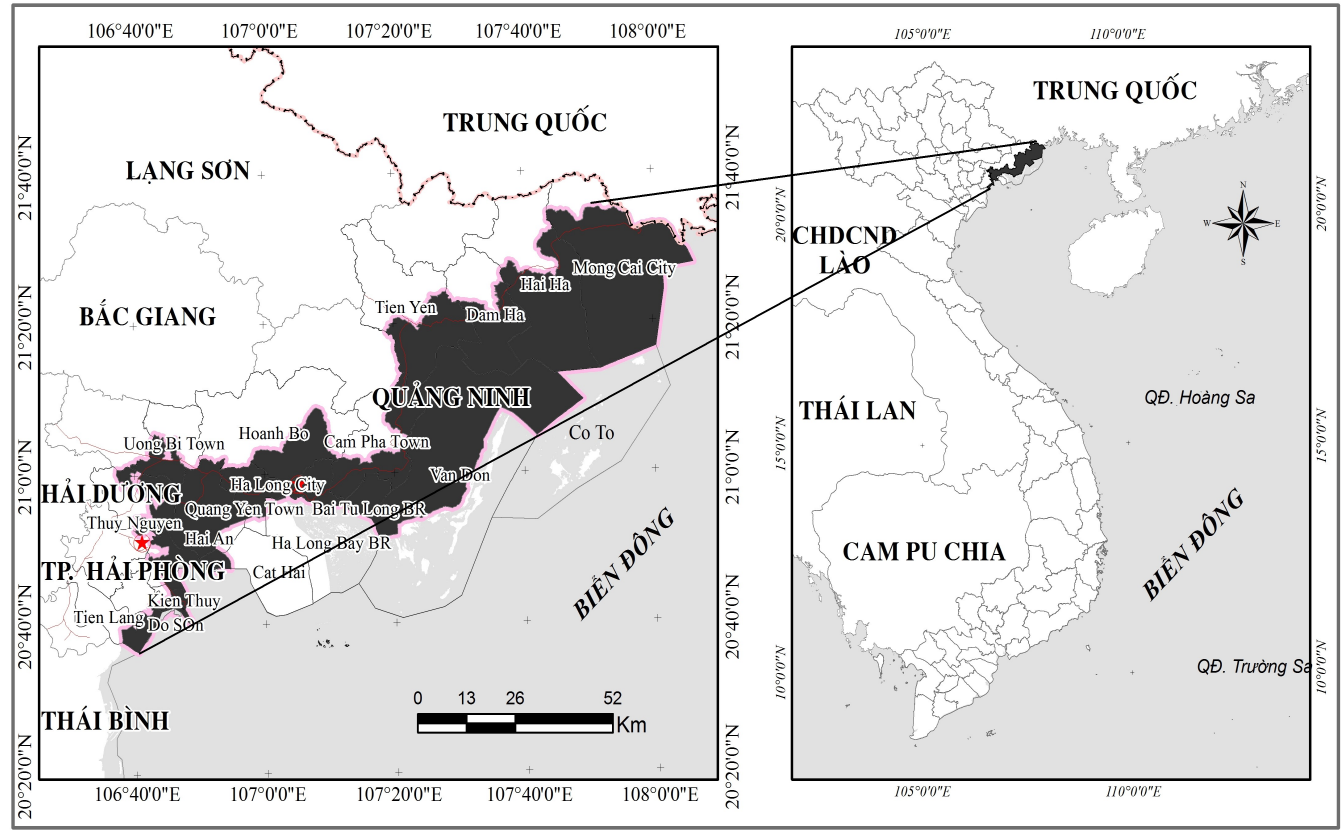

Hình 1. Sơ đồ khu vực nghiên cứu.

- Phương pháp điều tra thực địa: Tổ chức điều tra theo tuyến và theo điểm ở các khu vực nghiên cứu với sự tham gia của các chuyên gia trong các lĩnh vực liên quan. Lựa chọn các điểm khảo sát cụ thể theo đặc thù từng lĩnh vực. Tại các điểm khảo sát, ghi nhận sự phân bố, mật độ phân bố hoặc số lượng cá thể của các đối tượng điều tra chính. Ghi nhận hiện trạng, sự có mặt của các đối tượng thứ yếu khác có ảnh hưởng đến đối tượng điều tra chính. Đánh giá DĐSH các HST ĐNN áp dụng theo hướng dẫn về điều tra các hệ sinh thái biển và ven biển 8 , và quần xã thực vật trên ĐNN 7 , tập trung điều tra thành phần loài, phân bố các loài cỏ thủy sinh, các loài tảo; phân bố các sinh cảnh đất ngập nước, thành phần loài và cấu trúc thảm thực vật, thành phần loài hệ động vật (tập trung vào nhóm Thân mềm và Giáp xác); thành phần loài và phân bố của các loài cá, trữ lượng, mùa đánh bắt các loài cá tại khu vực nghiên cứu.

- Hệ thống phân loại và danh pháp: Toàn bộ các loài có mặt ở khu vực ĐNN ven biển Đông Bắc Bộ được chuẩn hóa dữ liệu theo từng cấp độ từ giới, ngành, lớp, bộ, họ đến loài làm có sở so sánh, thống kê sự đa dạng loài theo các sinh cảnh và HST khác nhau. Theo đó, tổng hợp, chuẩn hóa và sắp xếp theo các hệ thống phân loại, danh pháp theo các dữ liệu công bố: thực vật bậc cao 91023 , các loài tảo, các loài thú 1112, các loài chim 1314, các loài bò sát 15 , các loài cá 16 , Cá 20, Động vật biển không xương sống 21, Tảo 22.

- Danh mục loài quý hiếm: Các loài động thực vật quý hiếm được xác định dựa theo dữ liệu và danh mục của Sách đỏ Việt Nam (2007) 1718 và IUCN (2020) 24.

\section{Kết quả và thảo luận}

\subsection{Kết quả khảo sát thực địa các sinh cảnh đất ngập nước}

Trên cơ sở kết quả điều tra thực địa đã xác định được các đơn ưu và ưu hợp thực vật của các sinh cảnh khác nhau trong loạt diễn thế đất ngập nước ở khu vực ven biển Đông Bắc. Kết quả cụ thể như sau:

- Các đơn ưu gồm các sinh cảnh chỉ mọc thuần 1 loài trên nền địa hình và thổ nhưỡng đơn giản, thuần nhất và khá bằng phẳng hoặc sinh cảnh có 1 loài chiếm ưu thế gần như tuyệt đối so với các loài khác: Quần thể Mắm trên bãi bùn khá chặt ở Hải Hà; Quần thể Trang trên bùn lỏng ở Đồng Rui, Tiên Yên, bao quanh bởi các quần xã ngập mặn tiên phong như Mắm, Sú cong; Quần thể Đước vòi được sử dụng làm ao nuôi thủy hải sản quảng canh ở Quảng 
Yên; Quần thể Giá ở trên các gò đất nổi xen kẽ các vùng ĐNN ở Đồng Rui, Tiên Yên; Quần thể Bồn Bồn trên ĐNN trong đê, ít chịu ảnh hưởng bởi thủy triều ở Bạch Đằng; Quần xã Mắm tiên phong trên bùn nhão khu vực Đồng Rui, Tiên Yên; Quần xã tiên phong Sú cong trên bùn lỏng ở Đồng Rui, Tiên Yên; Quần xã Trang ven khu vực cửa sông Bạch Đằng ở Hải Phòng (đây là quần xã rừng trồng phòng hộ chắn sóng khu vực cửa sông); Quần xã Đâng trên bùn lỏng lòng sông ở Đồng Rui được bao quanh bởi các quần xã tiên phong là Mắm và Sú cong; Quần xã Bần tại khu vực rừng phòng hộ chắn sóng ven biển ở Tiên Lãng, Hải Phòng - quần xã gần như thuần loại Bần với nhiều cây gỗ cao, khép tán; Quần xã Củ năn trên ĐNN trong đê, ít chịu ảnh hưởng bởi thủy triều và chịu ảnh hưởng nhẹ của hoạt động canh tác ở Tiên Lang và Quần xã Bần rừng phòng hộ chắn sóng khu vực cửa sông;

- Các ưu hợp khác: sinh cảnh có sự đan xen của một số loài khác nhau trên nền địa hình và thổ nhưỡng đa dạng hơn, loài tiên phong là cơ sở để loài cận ưu thế xuất hiện: Ưu hơp Đâng + Mắm + Sú cong trên nền bùn lỏng lòng sông ở Đồng Rui, tiếp giáp giữa quần xã tiên phong (Mắm, Sú) và ưu hợp Đâng, Trang ổn định hơn ở phía trung tâm mỗi mảng rừng ngập mặn tại đây; Ưu hơp Đâng + Trang trên nền bùn lỏng lòng ở phía trung tâm mỗi mảng rừng ngập mặn tại Đồng Rui; Ưu hợp Mắm + Vẹt dù + Bần trên đất bán ngập nước vùng cửa sông Quảng Yên, là ưu hợp mặc dù chỉ gồm các cây ưa mặn nhưng đã tiến rất sát tới HST trên cạn khi nền đất chủ yếu ngang bằng với mực thủy triều; Ưu hợp Mắm + Sú cong + Tra làm chèo phía ngoài đê bao khu vực nuôi trồng thủy hải sản quảng canh tại Quảng Yên, bên canh cây ưa mặn thì sát bờ đê xuất hiện các loài chịu mặn mọc từ mức thủy triều trở lên; Uu hợp Trang + Tra làm chèo + Bình bát hình thành ở khu vực đất bán ngập nước vùng cửa sông Bạch Đằng.

Ngoài loài ưa mặn chính là Trang, thì Tra làm chèo và Bình bát là những loài chịu mặn, xuất hiện chủ yếu khi nền đất của HST được nâng lên bằng hoặc cao hơn mức triều một chút. Ưu hợp này còn có thêm sự xuất hiện của các loài cây bụi và thân thảo khác (loài chịu mặn).

Ưu hợp Giá + Bình bát + Tra làm chèo + Bần hình thành trên các khu vực ven sông, rất ít khi phải chịu tác động của thủy triều nhưng đất nhiễm mặn. Quần xã này chỉ còn những cây chịu mặn mà không có các loài ưa mặn ở Quảng Yên. Các loài thân thảo bắt đầu xuất hiện, chủ yếu thuộc họ Hòa thảo (Poaceae) nhưng không đáng kể.

\subsection{Hiện trạng các hệ sinh thái đất ngập nước}

Rừng ngập mặn tự nhiên: Rừng ngập mặn phân bố trải dài dọc theo vùng ven biển Đông Bắc, tuy nhiên, hình thái, cấu trúc, nguồn gốc thì mỗi nơi một khác. Khu vực Quảng Ninh, hầu hết các cửa sông hình phễu nên diện tích bồi lắng lấn biến ít, dẫn đến RNM phân bố không liên tục, mức độ ngập mặn lớn hơn so với khu vực Hải Phòng nơi cửa sông châu thổ mang lượng lớn phù sa bồi lắng lên diện tích ven biển lớn hơn 6 . Do có nguồn gốc hình thành khác nhau, động lực hải văn khác nhau do có sự can thiệp của con người nên hình thành ra nhiều loại hình thái RNM khác nhau ở khu vực nghiên cứu và mỗi hình thái sẽ tương ứng với một cấu trúc đặc trưng. Sự phân bố của các loài ưu thế trong các quần xã thực vật ngặp mặn phía ngoài đê bao thể hiện những mức độ tác động khác nhau của thủy triều cũng như sự ổn định và thành phần của nền đáy. Ở các vùng ngập triều thấp, Mắm, Sú thường là các loài phân bố ở rìa ngoài cùng, tiếp theo là sự xuất hiện của Trang, Vẹt dù và sau cùng là Đâng, Giá, lên cao nhất là Bần chua. Mặc dù có sự phân hóa khá rõ nhưng nhiều khu vực do mức ngập sau và dốc, các loài này có xu hướng mọc đan xen với nhau trong khi ở một số bãi bùn triều nông, chúng lại có xu hướng dãn ra làm thành những quần xã đơn ưu, đa ưu khá lớn. Như mô trả trong phần diễn thế sinh thái, các quần xã thực vật rừng ngập mặn phía ngoài đê bao gồm có: quần xã tiên phong Mắm biển (Avicennia marina), quần xã tiên phong Sú cong (Aegiceras corniculatum), quần xã Trang (Kandelia candel) + Vẹt dù (Bruguiera gymnorrhiza), quần xã Đâng (Rhizophora mucronata) + Trang (Kandelia candel) + Vẹt dù (Bruguiera gymnorrhiza) và quần xã Bần chua (Sonneratia caseolaris). 
Rừng ngập mặn tự nhiên được cải tạo: Ở phía trong đê, rừng ngập mặn có nguồn gốc tự nhiên nhưng được người dân cải tạo, đắp bờ, nạo kênh tạo vùng khoanh nuôi trồng thủy hải sản và có thể trồng bổ sung cây rừng ngập mặn. Do đó, cấu trúc rừng này cũng khá đơn giản, thường chỉ có một loài cây ưu thế chính là Đước hoặc Đưng/ Đâng. Khu vực đầm nuôi được tận dụng từ những vùng có sự ổn định nền đáy nhất định và cây rừng ngập mặn lên khá cao, có hệ rễ khí sinh lớn, là nơi trú ngụ tốt cho Tôm, Cua. Do vậy, những quần xã Đâng + Trang thường được khai thác, cải tạo thành khu vực nuôi quảng canh (tôm, cua, cá). Ở đó, khoảng $20-40 \%$ diện tích cây rừng ngập mặn được giữ lại trong khi các diện tích khác được đào sâu hơn làm nơi tích trữ nước và thuận tiên cho việc chăm nuôi của trang trại. Rừng ngập mặn trồng phòng hộ: Rừng ngập mặn có nguồn gốc trồng tập trung ở khu vực phía Hải Hòng, từ cửa Bạch Đằng đến Văn Úc, là rừng phòng hộ chắn sóng ven biển đa số chỉ có 1-2 loài ưu thế, rừng trồng thành dải dài, bề rộng lên đến hơn $600 \mathrm{~m}$. Ngoài ra, ở Quảng Ninh cũng có một số khu vực trồng rừng ngập mặn bổ sung cho diện tích rừng ngập mặn trước đó đã bị khai phá làm ao đầm nuôi trồng thủy hải sản, tuy nhiên, rừng ngập mặn trồng ở Quảng Ninh khá thưa và bị chia cắt nhiều.

Theo khảo sát, rừng ngập mặn tại xã Kiến Thụy, Hải Phòng được trồng từ 1999-2000 5. Rừng nằm sát đê biển, có chiều rộng $670 \mathrm{~m}$ gồm hai loài Bần chua (Sonneratia caseolaris) và Trang (Kandelia obovata). Dải ngoài cùng của rừng là rừng Bần chua rộng $200 \mathrm{~m}$, tiếp theo về phía lục địa là dải rừng trồng thuần cây Trang, rộng $200 \mathrm{~m}$. Dải rừng sát đê hỗn hợp bần trồng xen với trang, có chiều rộng $270 \mathrm{~m}$. Dải rừng phía biển là rừng bần thuần loài, cây bần cách đều nhau do khi trồng qui định. Bần chua che phủ $93 \%$. Tầng tán cách gốc cây từ dưới mặt đất lên đồng đều khoảng 70-90 cm. Tại khu vực này, tốc độ tăng trưởng của cây khá lớn so với các khu vực lân cận. Rừng tương đối đồng đều về về kích thước thân và chiều cao thân cây: đường kính thân tập trung hơn trong khoảng $18-35 \mathrm{~cm}$ và chiều cao cây ưu thế trong nhóm 12-25 $\mathrm{m}$. Dải rừng thuần Trang nằm sát phía trong rừng bần có mật độ $0,7 \mathrm{~m} \times 0,70$ $\mathrm{m}$, tán lá phát triển tốt đều và phân cành cách gốc cây từ mặt bãi từ khoảng $40 \mathrm{~cm}$ trở lên, mật độ hơn 16.000 cây/ha, chiều cao trung bình trong khoảng 4-6 m. Khảo sát tại Kiến Thụy và Tiên Lãng (Hải Phòng) năm 2020 cho thấy, Bần chua được trồng từ trước năm 2000 và đạt chiều cao trung bình 18-25 m, đường kính thân khá lớn, đạt trên $25 \mathrm{~cm}$. Mọc xen dưới tán Bần chua là các loài ưa mặn như Mắm, Đâng, Trang, Vẹt dù, Bình bát, Vạng hôi, Sậy, Cói, Sú cong,... và vùng sát bờ đê thường có thêm các loài chịu được mặn như Cóc kèn, Tra làm chèo, Tra lâm vồ, Keo dậu,...

HST vùng cửa sông: HST vùng cửa sông bao gồm hai phần là quần xã thực vật ven bờ (bao gồm cả trên cạn và bán ngập nước) và quần xã sinh vật thủy sinh trong phạm vi vùng nước giữa hai bờ và vào sâu trong sông đến nơi có độ muối dưới $1 \%$ và phía ngoài là vùng biển nông, thảm cỏ biển-nơi có độ muối trên $5 \%$ hoặc các khu vực rừng ngập mặn, vùng gian triều khác. Các loài thực vật có mạch trên cạn chủ yếu được tìm thấy ở ven bờ, bao gồm 215 loài, trong đó có cả một số loài ưa mặn, chịu mặn, bán ngập nước hoặc ngập nước như Trang (Kandelia obovata), Vẹt (Bruguiera spp.), Ổ rô (Acanthus spp.), Mắm (Avicennia spp.), Quao nước (Dolichandrone spathacea), Giá (Excoecaria agallocha), Tra làm chèo (Hibiscus tiliaceus), Tra lâm vồ (Thespesisa populnea), Bần chua (Sonneratia caseolaris),... và những loài thân thảo chịu ngập, chịu mặn, ưa mặn phổ biến như Ráng biển (Acrostichum aureum), Rau muống biển (Ipomoea pes-caprae), Náng hoa trắng (Crinum asiaticum), Sậy (Phragmites spp.), Bồn bồn (Typha angustifolia), San (Paspalum spp.), Hến biển (Scirpus littoralis), Năn (Eleocharis spp.),... Do điều kiện địa hình các bãi lầy cửa sông nhỏ hẹp chạy theo bờ sông nên kiểu thảm này cũng là các nhóm cây mọc rải rác chạy dài theo bờ sông. Chiều cao trung bình của nhóm cây gỗ với các đại diện là Bần Vẹt dù và Đâng là từ $3-5 \mathrm{~m}$, do quá trình bồi lắng phù sa nên trong HST này có sự phân bố của Sú ở mép ngoài của các quần xã phân bố tai đây và có chiều cao trung bình $2,5 \mathrm{~m}$ (có điểm lên đến $4 \mathrm{~m}$ ).

Trảng cỏ bán ngập nước: Trảng cỏ ngập mặn hoặc bán ngập mặn, ngập lợ ở khu vực ven biển Đông Bắc bao gồm cả một số ít diện tích là đồng Cói chủ yểu có nguồn gốc tự nhiên 
hoặc bán tự nhiên. Ở đó, nước mặn xâm nhập do thủy triều lên một số vùng đất trũng nội đồng hoặc đôi khi vùng đất nhiễm mặn bị cô lập do các hoạt động xây dựng, canh tác, thủy lợi của con người, được nước mưa pha trộn nên độ mặn giảm xuống tương tự như nước lợ. HST này được hình thành chủ yếu do một hoặc một vài loài thực vật bậc cao có mạch chịu ngập, ưa lợ mọc thuần loài trong các đầm nước lợ ven biển có lá nổi trên mặt nước hoặc thân nhô cao khỏi mặt nước. Ngoài ra còn có các thực vật phù du, động vật thủy sinh khác. Các HST này thường bị cô lập hoặc có thể kết nối với các HST thủy sinh khác khi triều lên.

Các loài thực vật bậc cao có mạch thân thảo chịu ngập phát triển mạnh như Hến biển (Scirpus littoralis), Cỏ ngạn (Scirpus kimsonensis), Bồn bồn (Typha angustifolia), Năn (Eleocharis spp.), Cói (Cyperus malaccensis), Thủy trúc (Cyperus rotundus),... và xa hơn là Sen (Nelumbo nucifera), Rong lá sắn (Hydrocharis dubia), Bèo lục bình (Eichhornia crassipes $), \ldots$ chúng thường tồn tại thành một đơn ưu nhưng đôi khi cũng có các loài cỏ khác thuộc họ Hòa thảo (Poaceae) hay Cói (Cyperaceae), Rau mương (Ludwigia spp.), Ráng biển (Acrostichum aureum), Mai dương (Mimosa pigra), Rau bợ (Marsilea quadrifolia), Nhọ nồi (Eclipta prostrata), Nghể (Polygonum spp.), Rong đuôi chồn (Ceratophyllum demersum), Nhĩ cán vàng (Utricularia aurea), Rong xương cá (Myriophyllum dicoccum), Hồ thảo (Limnophyton obtusifolium), Từ cô (Sagittaria sagittifolia)... mọc xen, chủ yếu ở vùng nông hơn hoặc ven bờ.

Thảm cỏ biển: Phân bố của cỏ biển ven bờ tỉnh Quảng Ninh đã từng được ghi nhận tại Đầm Buôn, vụng Hà Cối, vụng Đầm Hà, bãi Quán Lạn và bãi Nhà Mạc. Tuy nhiên theo các kết quả nghiên cứu mới nhất hiện nay cỏ biển chỉ còn phân bố nhiều nhất là tại bãi Nhà Mạc (khoảng 100 ha), một số diện tích nhỏ ven các đảo Cô Tô và Quán Lạn, rải rác ở mức nước 0,7-6 m, thường không có cây ngập mặn. Quần xã này có một đặc trưng duy nhất, đó là sự xuất hiện của 4 loài cỏ biển là Cỏ xoan (Halophila beccarii), Cỏ xona nhỏ (H. ovalis), Cỏ lươn nhật (Zostera japonica) và Cỏ kim (Ruppia maritima) và mặc dù chỉ bao gồm các loài thủy sinh nhưng vẫn chịu ảnh hưởng lớn của thùy triều khi các loài cỏ biển vẫn có thời điểm không bị ngập hoàn toàn trong ngày.

BẢN ĐỔ PHÂN BỐ Hệ SINH THÁI VEN BIỂN ĐÔNG BĂC VIỆT NAM NĂM 2020

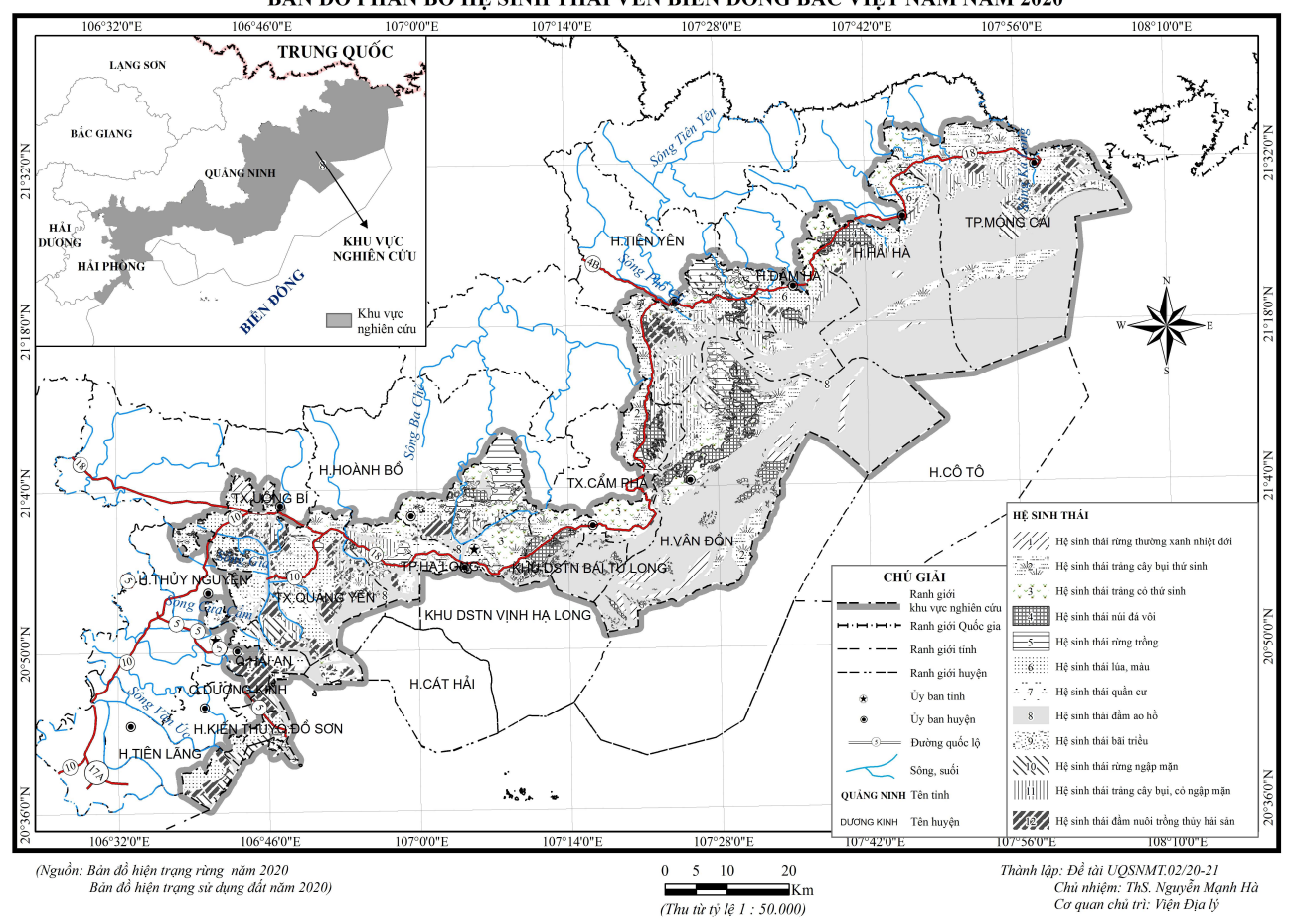

Hình 2. Bản đồ các hệ sinh thái vùng ven biển đông Bắc Việt Nam (thu từ tỷ lệ 1:50.000). 


\section{3. Đa dạng loài của các hệ sinh thái}

Đa dạng loài HST rừng ngập mặn: Đã sơ bộ thống kê được 1379 loài sinh vật có vùng phân bố trong HST RNM Đông Bắc Việt Nam, bao gồm 559 loài thực vật và 770 loài động vật đa bào cùng với 50 loài sinh vật đơn bào khác (Bảng 1). Với nền đáy chưa ổn định và thường chịu chế độ của thủy triều, có thể nói, RNM rất đa dạng về các nhóm loài sinh vật, chủ yếu là các loài ưa mặn, chịu mặn, thủy sinh đến bán ngập nước. Bên cạnh đó, RNM còn là sinh cảnh trú ngụ của nhiều loài thủy sinh nên ở đây cũng là nơi kiếm ăn của nhiều loài động vật có kích thước lớn hơn, kể cả sinh vật thủy sinh và trên cạn.

Đánh giá ban đầu Thực vật phù du (Phytoplankton) tìm thấy trong các RNM ven biển Đông Bắc Việt Nam có 199 loài, chủ yếu thuộc về Tảo Si lic (Bacillariophyceae) với 163 loài, Tảo lục (Chlorophyta) với 31 loài và 5 loài Tảo đỏ (Rhodophyta). Đa số là những loài có tính rộng muối phân bố rộng rãi từ các vùng ven bờ đến các vùng biển khơi. Đây được coi là nguồn dinh dưỡng sơ cấp phong phú cho toàn bộ lưới thức ăn và chuỗi thức ăn của HST này.

Động vật phù du (Zooplankton) trong HST này cũng rất phong phú. Đã sơ bộ xác định có 98 loài động vật phù dù đa bào cùng với 50 loài sinh vật đơn bào khác, cùng với Thực vật phù du, đây là nguồn dinh dưỡng đáng kể cho các động vật đáy, Cá và sau đó là Chim. Động vật đáy (Zoobenthos) rất đa dạng với 394 loài trong đó, Giun đốt có 34 loài, Thân mềm có 172 loài gồm 105 loài Hai mảnh vỏ, 12 loài chân đầu, 55 loài chân bụng; 86 loài giáp xác; 2 loài Giun biển và 2 loài Hàm tơ. Hầu hết những loài này đều là nguồn hải sản quan trọng của HST cũng như đời sống của người dân địa phương.

Khu hệ cá: Với sự phong phú của nguồn thức ăn và sự đa dạng về nơi cư ngụ trong rừng ngập mặn, mặc dù phải chịu chi phối của thủy triều khoảng 1 nửa thời gian trong ngày sinh cảnh này không có nước nhưng khu hệ cá ở RNM ven biển Đông Bắc khá phong phú. Kết quả nghiên cứu khu hệ cá trong HST RNM xác định được 183 loài cá phân bố trong HST này trong đó có 4 loài cá Mang tấm và 179 loài Cá vây tia.

Bảng 1. Kết quả phân tích cấu trúc quần xã sinh vật của hệ sinh thái rừng ngập mặn ven biển Đông Bắc.

\begin{tabular}{|c|c|c|c|c|}
\hline Giới & Ngành & Lớp & Tên Việt Nam & Số loài \\
\hline Bacteria & Cyanobacteria & & Vi khuẩn lam & 28 \\
\hline Chromista & Myzozoa & & Myzozoa & 15 \\
\hline \multirow[t]{2}{*}{ Protozoa } & & & Động vật nguyên sinh & 7 \\
\hline & Euglenozoa & & Tảo mắt & 7 \\
\hline \multirow[t]{13}{*}{ Plantae } & & & Thực vật & 559 \\
\hline & Rhodophyta & & Tảo đỏ & 5 \\
\hline & Ochrophyta & Bacillariophyceae & Tảo vàng & 163 \\
\hline & Chlorophyta & & Tảo lục & 31 \\
\hline & & Chlorophyceae & Lớp Tảo lục & 9 \\
\hline & & Trebouxiophyceae & & 3 \\
\hline & & Ulvophyceae & Lớp Tảo vòng & 8 \\
\hline & & Zygnematophyceae & & 11 \\
\hline & Pteridophytes & & Dương xỉ & 23 \\
\hline & Angiosperms & & Hạt kín & 337 \\
\hline & Eudicots & & Lớp Hai lá mầm & 256 \\
\hline & Magnoliids & & Lớp Ngọc lan & 6 \\
\hline & Monocots & & Lớp Một lá mầm & 75 \\
\hline \multirow[t]{6}{*}{ Animalia } & & & Động vật & 770 \\
\hline & Annelida & & Giun đốt & 34 \\
\hline & Mollusca & & Thân mềm & 172 \\
\hline & & Bivalvia & Lớp Hai mảnh vỏ & 105 \\
\hline & & Cephalopoda & Lớp Chân đầu & 12 \\
\hline & & Gastropoda & Lớp Chân bụng & 55 \\
\hline
\end{tabular}


Tạp chi Khí tương Thủy văn 2022, 734, 13-27; doi:10.36335/VNJHM.2022(734).13-27

\begin{tabular}{|c|c|c|c|c|}
\hline Giới & Ngành & Lớp & Tên Việt Nam & Số loài \\
\hline \multirow{6}{*}{\multicolumn{2}{|c|}{ Arthropoda }} & & Chân khớp & 184 \\
\hline & & Branchiopoda & & 6 \\
\hline & & Crustacea & Lớp Giáp xác & 86 \\
\hline & & Hexanauplia & Lớp Chân kiếm & 18 \\
\hline & & Insecta & Lớp Côn trùng & 67 \\
\hline & & Malacostraca & & 5 \\
\hline \multirow{3}{*}{\multicolumn{2}{|c|}{ Sipuncula }} & & Giun biển & 2 \\
\hline & & Sipunculidea & Lớp Sá sùng & 1 \\
\hline & & Phascolosomatidea & Lớp Sâm đất & 1 \\
\hline & Chaetognatha & & Hàm tơ & 2 \\
\hline \multirow{8}{*}{\multicolumn{2}{|c|}{ Chordata }} & & Có xương sống & 376 \\
\hline & & Appendicularia & & 4 \\
\hline & & Thaliacea & & 1 \\
\hline & & Elasmobranchii & Lớp Cá mang tấm & 4 \\
\hline & & Actinopterygii & Lớp Cá vây tia & 179 \\
\hline & & Reptilia & Lớp Bò sát & 3 \\
\hline & & Aves & Lớp Chim & 150 \\
\hline & & Mammalia & Lớp Thú & 35 \\
\hline
\end{tabular}

Sự phong phú của của khu hệ cá và động vật thủy sinh, người dân địa phương đã tận dụng điều này để phát triển hệ thống đầm nuôi quảng canh rất phổ biến. Nuôi quảng canh sẽ tiết kiệm đáng kể chi phí thức ăn cho vật nuôi, mang lại hiệu quả kinh tế lớn cho người dân. Khu hệ chim. Theo thống kê sơ bộ, có 150 loài chim bao gồm cả loài có vùng cư trú tại địa phương và các loài chim di cư (rừng ngập mặn này còn là nơi trú đông của nhiều loài chim phương Bắc di cư tránh rét hàng năm) xuất hiện tại các sinh cảnh RNM ven biển Đông Bắc, trong đó hầu hết các loài chim nước có mặt trên toàn vùng ven biển Đông Bắc đều tìm thấy ở khu vực RNM. Do có sự xuất hiện của yếu tố mặn, RNM không phải là môi trường sinh trưởng tốt của hầu hết các loài lưỡng cư và bò sát vì thế nhóm loài này chỉ có 3 loài rắn nước được tìm thấy trong các HST rừng ngập mặn ven biển Đông Bắc. Bên cạnh đó, một số loài thú nhỏ trong Bộ gặm nhấm (Rodentia) và Dơi (Chiroptera) cũng được cho là có vùng phân bố ở các khu rừng ngập mặn làm tổng số loài thú ở đây lên đến 35 loài. Mặc dù vậy, chúng tôi cho rằng một số loài thú cỡ trung bình có thể đã lâu không còn xuất hiện tại khu vực như Lợn rừng, Rái cá và các loài Cầy. Đa dạng loài HST vùng cửa sông: Đã thống kê được 1024 loài sinh vật có vùng phân bố ở các cửa sông Đông Bắc Việt Nam, trong đó có 469 loài thực vật với 236 loài tảo và 233 loài thực vật bậc cao có mạch; 498 loài động vật đa bào bao gồm 333 loài động vật có xương sống, chủ yếu là cá (105 loài) và chim (154 loài); động vật thủy sinh khác đa dạng nhất là nhóm chân khớp với 124 loài, trong đó chủ yếu trong lớp Giáp xác (Crustacae, 47 loài) và côn trùng (36 loài). Ngoài ra còn ghi nhận 55 loài sinh vật đơn bào thủy sinh khác bao gồm 28 loài vi khuẩn lam (Cyanobacteria), 20 loài động vật đơn bào Myozoa và 7 loài Tảo mắt (Euglenozoa) thể hiện Bảng 2.

Bảng 2. Kết quả phân tích cấu trúc quần xã sinh vật của hệ sinh thái vùng cửa sông Đông Bắc.

\begin{tabular}{ccccc}
\hline Giới & Ngành & Lớp & Tên Việt Nam & Số loài \\
\hline Bacteria & & & Vi khuẩn & \\
& Cyanobacteria & Cyanobacteria & Vi khuân lam & 28 \\
$\begin{array}{c}\text { Chromista } \\
\text { Protozoa }\end{array}$ & Myzozoa & Myzozoa & Myzozoa & 20 \\
& & & Động vật nguyên sinh & \\
Plantae & Euglenozoa & & Tảo mắt & 7 \\
& & & Giới Thực vật & \\
& Ochrophyta & & Tảo vàng & 203 \\
& & Bacillariophyceae & Lớp Tảo Si lic & 200 \\
& \multirow{2}{*}{ Chlorophyta } & Phaeophyceae & Lớp Tảo vàng & 3 \\
& & & Tảo lục & 33 \\
& & Chlorophyceae & Lớp Tảo lục & 20 \\
\hline
\end{tabular}


Tạp chi Khi tương Thủy văn 2022, 734, 13-27; doi:10.36335/VNJHM.2022(734).13-27

\begin{tabular}{|c|c|c|c|c|}
\hline Giới & Ngành & Ló́p & Tên Việt Nam & Số loài \\
\hline \multirow{29}{*}{ Animalia } & \multirow{9}{*}{$\begin{array}{l}\text { Pteridophytes } \\
\text { Angiosperms }\end{array}$} & Trebouxiophyceae & & 3 \\
\hline & & Ulvophyceae & Lớp Tảo vòng & 4 \\
\hline & & Zygnematophyceae & & 6 \\
\hline & & \multirow[t]{2}{*}{ Pteridophytes } & Dương xỉ & 18 \\
\hline & & & Hạt kín & 215 \\
\hline & & Eudicots & Lớp Hai lá mầm & 173 \\
\hline & & Magnoliids & Lớp Ngọc lan & 2 \\
\hline & & Monocots & Lớp Một lá mầm & 40 \\
\hline & & & Giới Động vật & \\
\hline & \multirow{4}{*}{$\begin{array}{l}\text { Annelida } \\
\text { Mollusca }\end{array}$} & Annelida & Giun đốt & 12 \\
\hline & & & Thân mềm & 24 \\
\hline & & Bivalvia & Lớp Hai mảnh vỏ & 10 \\
\hline & & Gastropoda & Lớp Chân bụng & 14 \\
\hline & \multirow[t]{6}{*}{ Arthropoda } & & Chân khớp & 124 \\
\hline & & Branchiopoda & & 5 \\
\hline & & Crustacea & Lớp Giáp xác & 47 \\
\hline & & Hexanauplia & Lớp Chân kiếm & 27 \\
\hline & & Insecta & Lớp Côn trùng & 36 \\
\hline & & Malacostraca & & 8 \\
\hline & \multirow{10}{*}{$\begin{array}{c}\text { Chaetognatha } \\
\text { Chordata }\end{array}$} & Chaetognatha & Hàm tơ & 5 \\
\hline & & & Có xương sống & 333 \\
\hline & & Appendicularia & & 8 \\
\hline & & Thaliacea & & 1 \\
\hline & & Elasmobranchii & Lớp Cá mang tấm & 3 \\
\hline & & Actinopterygii & Lớp Cá vây tia & 102 \\
\hline & & Amphibia & Lớp Lưỡng cư & 16 \\
\hline & & Reptilia & Lớp Bò sát & 21 \\
\hline & & Aves & Lớp Chim & 154 \\
\hline & & Mammalia & Lớp Thú & 28 \\
\hline
\end{tabular}

Các loài thực vật có mạch trên cạn chủ yếu được tìm thấy ở ven bờ, bao gồm 215 loài, trong đó có cả một số loài ưa mặn, chịu mặn, bán ngập nước hoặc ngập nước như Trang (Kandelia obovata), Vẹt (Bruguiera spp.), Ô rô (Acanthus spp.), Mắm (Avicennia spp.), Quao nước (Dolichandrone spathacea), Giá (Excoecaria agallocha), Tra làm chèo (Hibiscus tiliaceus), Tra lâm vồ (Thespesisa populnea), Bần chua (Sonneratia caseolaris),... và những loài thân thảo chịu ngập, chịu mặn, ưa mặn phổ biến như Ráng biển (Acrostichum aureum), Rau muống biển (Ipomoea pes-caprae), Náng hoa trắng (Crinum asiaticum), Sậy (Phragmites spp.), Bồn bồn (Typha angustifolia), San (Paspalum spp.), Hến biển (Scirpus littoralis), Năn (Eleocharis spp.),...

Do điều kiện địa hình các bãi lầy cửa sông nhỏ hẹp chạy theo bờ sông nên kiểu thảm này cũng là các nhóm cây mọc rải rác chạy dài theo bờ sông. Chiều cao trung bình của nhóm cây gỗ với các đại diện là Bần Vẹt dù và Đâng là từ $3-5 \mathrm{~m}$, do quá trình bồi lắng phù sa nên trong HST này có sự phân bố của Sú ở mép ngoài của các quần xã phân bố tai đây và có chiều cao trung bình $2,5 \mathrm{~m}$ (có điểm lên đến $4 \mathrm{~m}$ ). Những thực vật ngập mặn này đóng vai trò "vật trụ", lôi cuốn vào đây hàng loạt các loài động thực vật khác để tạo nên những hệ sinh thái đa dạng và giàu có, kể cả ở vùng triều và dưới triều.

Các loài thực vật nổi (Phytoplankton) vùng cửa sông Đông Bắc đã ghi nhận với 236 loài thuộc hai ngành là Tảo vàng (Ochrophyta, 203 loài, tập trung chủ yếu trong lớp Tảo Si licBacillariophyceae với 200 loài) và Tảo lục (Chlorophyta, 33 loài-chủ yếu là lớp tảo Lục Chlorophyceae với 20 loài). Các loài động vật nổi (Zooplankton) được ghi nhận ở vùng sinh thái cửa sông có 77 loài, chủ yếu thuộc nhóm Chân kiếm (Hexanauplia) và các côn trùng thủy sinh (Insecta). Động vật đáy (Zoobenthos) tại khu vực cửa sông Đông Bắc cũng được ghi nhận với 12 loài Giun đốt (Annelida), 10 loài Hai mảnh vỏ (Bivalvia), 14 loài chân bụng (Gastropoda), 5 loài rươi và 14 loài Giáp xác (Crustacea). Động vật đáy tập trung chính vào nhóm ăn lọc, ăn bùn, ít di động (giun nhiều tơ, thân mềm, giáp xác sống đáy...). 
Các nhóm này rất quan trọng, đóng vai trò như lực lượng bổ sung trong mắt xích thức ăn để tiêu thụ phần thức ăn sơ cấp dư thừa mà Zooplankton không sử dụng hết còn nằm dưới dạng phế liệu. Do vậy, sự hoạt động đồng bộ của toàn hệ thống đã tạo nên trong các hệ cửa sông nhiệt đới một năng suất sinh học cao, tương tự như năng suất của các rạn san hô và rừng mưa nhiệt đới.

Trong HST cửa sông Đông Bắc ghi nhận được 105 loài cá, trong đó cá Mang tấm (Elasmobranchii) có 3 loài và Cá vây tia (Actinopterygii) có 102 loài. Cá vùng cửa sông có nguồn gốc từ khu hệ cá biển, trong đó các đại diện của bộ cá Vược (Perciformes) thường đa dạng nhất do phổ sinh thái về độ mặn rất rộng và là loài ăn tạp. Nhiều loài là dạng cửa sông điển hình, nhiều loài cá biển rộng muối và một số loài cá nước ngọt thích nghi với độ muối thấp xâm nhập vào vùng cửa sông để kiếm ăn. Nói chung, cá cửa sông thường có kích thước nhỏ vì đây là bãi đẻ, nơi nuôi dưỡng của ấu trùng và cá con sau các mùa đẻ. Những loài cá từ vùng khơi thềm lục địa vào vùng cửa sông để kiếm ăn và sinh sản khá phong phú và chúng thường xuất hiện có chu kỳ liên quan với sự biến đổi có chu kỳ của độ muối trong vùng và chu kỳ mùa.

Động vật có xương sống khác ghi nhận ở khu vực cửa sông, chủ yếu là Bò sát (21 loài), lưỡng cư (16 loài) trực tiếp sống ở các sinh cảnh ven bờ tạo dựng bởi quần xã thực vật; ngoài ra cũng ghi nhận vùng phân bố của 28 loài thú nhỏ, nhiều nhất là Bộ gặm nhấm (Rodentia) và Dơi (Chiroptera). Các loài thú lớn khác trước đây có ghi nhận phân bố nhưng hiện tại có lẽ không còn sinh sống tại các cửa sông vùng Đông Bắc. Ngoài ra, vùng cửa sông cũng là nơi kiếm ăn chính của 154 loài chim, bao gồm cả chim dư cư, là là nơi trú ngụ của hầu hết các loài chim nước, như các bộ Chim lặn (Podicipediformes), Hạc (Ciconiiformes), Ngỗng (Anseriformes), Sếu (Gruiformes), Rẽ (Charadriiformes),...

Đa dạng loài của trảng cỏ ngập nước: thống kê được 433 loài sinh vật có mặt ở HST này, trong đó thực vật bậc cao có mạch có 95 loài, thực vật phù du có 131 loài chủ yếu là Tảo Si lic (Bacillariophyceae) với 78 loài và 46 loài Tảo lục (Chlorophyta); Động vật đa bào ghi nhận có 163 loài trong đó có 39 loài động vật nổi và 53 loài động vật đáy, 18 loài cá (chủ yếu là cá nước ngọt và nước lợ), 15 loài lưỡng cư, 11 loài bò sát và 66 loài chim (Bảng 3$)$. Có thể nói, mức độ đa dạng sinh học của HST trảng cỏ ngập nước khá thấp nếu so sánh với Rừng ngập mặn hoặc cửa sông.

Bảng 3. Kết quả phân tích cấu trúc quần xã sinh vật của trảng cỏ ngập nước ven biển Đông Bắc.

\begin{tabular}{ccclc}
\hline Giới & Ngành & Lớp & Tên Việt Nam & Số loài \\
\hline Bacteria & Cyanobacteria & & Vi khuẩn lam & 13 \\
Chromista & Myzozoa & & Myzozoa & 24 \\
Protozoa & Euglenozoa & & Tảo mắt & 7 \\
Plantae & & Thực vật & 226 \\
& Rhodophyta & & Tảo đỏ & 4 \\
& Ochrophyta & & Tảo vàng & 81 \\
& & Bacillariophyceae & Lớp Tảo Si lic & 78 \\
& & Phaeophyceae & Lớp Tảo vàng & 3 \\
& Chlorophyta & & Tảo lục & 46 \\
& & Chlorophyceae & Lớp Tảo lục & 20 \\
& & Trebouxiophyceae & & 3 \\
& & Ulvophyceae & Lớp Tảo vòng & 14 \\
& & Zygnematophyceae & & 9 \\
& Pteridophytes & & Dương xỉ & 6 \\
& Angiosperms & & Hạt kín & 89 \\
& Eudicots & & Lớp Hai lá mầm & 25 \\
& Monocots & & Lớp Một lá mầm & 64 \\
& & & Động vật & 163 \\
Animalia & Mollusca & & Thân mểm & 6 \\
& & & Bivalvia Hai mảnh vỏ & 4 \\
\hline
\end{tabular}




\begin{tabular}{|c|c|c|c|c|}
\hline Giới & Ngành & Lớp & Tên Việt Nam & Số loài \\
\hline & & Gastropoda & Lớp Chân bụng & 2 \\
\hline & Arthropoda & & Chân khớp & 47 \\
\hline & \multirow{8}{*}{ Chordata } & Branchiopoda & & 2 \\
\hline & & Crustacea & Lớp Giáp xác & 8 \\
\hline & & Insecta & Lớp Côn trùng & 37 \\
\hline & & & Có xương sống & 110 \\
\hline & & Actinopterygii & Lớp Cá xương & 18 \\
\hline & & Amphibia & Lớp Lưỡng cư & 15 \\
\hline & & Reptilia & Lớp Bò sát & 11 \\
\hline & & Aves & Lớp Chim & 66 \\
\hline
\end{tabular}

Đa dạng loài HST thảm cỏ biển: Trên cơ sở các nghiên cứu trước đây, kết hợp với khảo sát thực địa và đánh giá tổng hợp trên toàn vùng nghiên cứu, đã xác định HST thảm cỏ biển vùng ven biển Đông Bắc có 976 loài, trong đó, thực vật có 270 loài, động vật đa bào có 652 loài và 55 loài sinh vật đơn bào. Tất cả các loài đều có đời sống thủy sinh (Bảng 4). Thực vật bậc cao có mạch chỉ ghi nhận 8 loài trong HST cỏ biển nhưng tất cả đều là những loài hết sức quan trọng vì chúng làm nên cấu trúc đặc trưng của HST này, ngoài việc cung cấp một phần dinh dưỡng, cỏ biển còn là nơi trú ngụ và kiểm ăn của hầu hết các loài động vật thủy sinh khác trong khu vực. Cả 8 loài này đều là các loài cỏ biển thuộc hai họ Thủy thảo (Hydrocharitaceae) và Cỏ lươn (Zosteraceae), Cỏ kim (Ruppiaceae). Thực vật nổi và động vật nổi khá phong phú, với 262 loài thực vật phù du và 96 loài động vật nổi. Đây là nguồn thức ăn phong phú cho các loài động vật đáy và cá, HST này là nơi kiếm ăn và trú ngụ của 404 loài động vật đáy, 239 loài cá, bao gồm cả cá Vây tia và cá Mang tấm. Không ghi nhận các loài động vật có xương sống ở cạn có mặt trong HST này.

Bảng 4. Kết quả phân tích cấu trúc quần xã sinh vật của thảm cỏ biển ven bờ vùng Đông Bắc.

\begin{tabular}{|c|c|c|c|c|}
\hline Giới & Ngành & Lớp & Tên Việt Nam & Số loài \\
\hline Bacteria & Cyanobacteria & & Vi khuẩn lam & 28 \\
\hline Chromista & Myzozoa & & Myzozoa & 20 \\
\hline Protozoa & Euglenozoa & & Tảo mắt & 7 \\
\hline \multirow[t]{12}{*}{ Plantae } & & & Thực vật & 270 \\
\hline & Rhodophyta & & Tảo đỏ & 11 \\
\hline & Ochrophyta & & Tảo vàng & 208 \\
\hline & & Bacillariophyceae & Lớp Tảo Si lic & 204 \\
\hline & & Phaeophyceae & Lớp Tảo vàng & 4 \\
\hline & Chlorophyta & & Tảo lục & 43 \\
\hline & & Chlorophyceae & Lớp Tảo lục & 20 \\
\hline & & Trebouxiophyceae & & 3 \\
\hline & & Ulvophyceae & Lớp Tảo vòng & 14 \\
\hline & & Zygnematophyceae & & 6 \\
\hline & Angiosperms & & Hạt kín & 8 \\
\hline & Monocots & & Lớp Một lá mầm & 8 \\
\hline \multirow[t]{16}{*}{ Animalia } & & & Động vật & 652 \\
\hline & Annelida & & Giun đốt & 36 \\
\hline & Mollusca & & Thân mềm & 181 \\
\hline & & Bivalvia & Lớp Hai mảnh vỏ & 106 \\
\hline & & Cephalopoda & Lớp Chân đầu & 12 \\
\hline & & Gastropoda & Lớp Chân bụng & 63 \\
\hline & Arthropoda & & Chân khớp & 182 \\
\hline & & Branchiopoda & & 5 \\
\hline & & Crustacea & Lớp Giáp xác & 86 \\
\hline & & Hexanauplia & Lớp Chân kiếm & 29 \\
\hline & & Insecta & Lớp Côn trùng & 51 \\
\hline & & Malacostraca & & 8 \\
\hline & Chaetognatha & & Hàm tơ & 5 \\
\hline & Chordata & & Có xương sống & 248 \\
\hline & & Appendicularia & & 8 \\
\hline & & Thaliacea & & 1 \\
\hline
\end{tabular}




\begin{tabular}{|c|c|c|c|c|}
\hline Giới & Ngành & Lớp & Tên Việt Nam & Số loài \\
\hline & & Elasmobranchii & Lớp Cá mang tấm & 8 \\
\hline
\end{tabular}

Các loài nguy cấp, quý hiếm: Các loài sinh vật quý hiếm, đang bị đe dọa và cần bảo tồn ở HST ĐNN ven biển Đông Bắc sơ bộ xác định: Các loài thực vật quý hiếm theo SĐVN (2007): gồm 1 loài Nguy cấp (EN) là Cỏ ngạn (Scirpus kimsonensis) và 3 loài Sẽ nguy cấp (VU) là Ráng đuôi phụng bon (Drynaria bonii), Hà thủ ô đỏ (Fallopia multiflora) và Lát hoa (Chukrasia tabularis); Các loài động vật quý hiếm theo SĐVN (2007): có 2 loài Cực kỳ nguy cấp $(\mathrm{CR})$ là Cá bống bớp (Bostrichthys sinensis) và Rắn hổ mang chúa (Ophiophagus hannah); 9 loài nguy cấp (EN) bao gồm Cầy mực (Arctictis binturong), Rắn cạp nong (Bungarus fasciatus), Cá Chuối (Channa maculata), Cá mòi cờ hoa (Clupanodon thrissa), Rắn hổ mang thường (Naja naja), Cốc đế (Phalacrocorax carbo), Cò mỏ thìa (Platalea minor), Rắn ráo thường (Ptyas korros), Rắn ráo trâu (Ptyas mucosa) và 11 loài Sẽ nguy cấp (VU) là Rái cá vuốt bé (Aonyx cinerea), Bói cá lớn (Ceyx lugubris), Rắn sọc dưa (Coelognathus radiatus), Tắc kè (Gekko gecko), Cá mòi chấm (Konosirus punctatus), Rái cá thường (Lutra lutra), Cò lạo ấn độ (Mycteria leucocephala), Mòi cờ mõm tròn (Nematalosa nasus), Rồng đất (Physignathus cocincinus), Sóc đen (Ratufa bicolor) và Dơi lá tô ma (Rhinolophus thomasi); Các loài động vật theo IUCN (2020): gồm 3 loài Nguy cấp (EN) là Sam ba gai đuôi (Tachypleus tridentatus), Cá lành canh đỏ (Coilia mystus) và Cá thu chấm (Epinephelus akaara); 5 loài Sẽ nguy cấp (VU) là Cỏ nàn (Halophila beccarii), Cá Diếc mắt đỏ (Cyprinus carpio), Rắn cạp nia nam (Naja atra), Rắn cạp nia bắc (Ophiophagus hannah), Rắn lục mép trắng (Pelodiscus sinensis) và Cầy mực (Arctictis binturong); 9 loài gần nguy cấp là Chà là biển (Phoenix paludosa), Cá chình (Anguilla bicolor), Cá nầu (cá hói) (Boesemania microlepis), Cá uốp gai (Scomberomorus commerson), Cò lửa (Mycteria leucocephala), Choắt nhỏ (Limosa lapponica), Choắt lớn (Limosa limosa), Choắt bụng trắng (Limnodromus semipalmatus), Rái cá thường (Lutra lutra) và Sóc đen (Ratufa bicolor) cùng với 352 loài ít được quan tâm, 2 loài mối đe dọa thấp và 15 loài khác còn thiếu dữ liệu để đánh giá.

Trong số các loài ghi nhận theo SĐVN (2007) thì Hà thủ ô đỏ và Lát hoa được trồng, không phải phân bố tự nhiên nên mức độ quý hiếm cũng như giá trị bảo tồn không cao, sự phân bố của Ráng đuôi phụng cũng khá hạn chế khi chỉ gặp ở những nơi có cây gỗ cao, nhất là trong rừng thường xanh tự nhiên trên cạn, rừng trồng ngập mặn ưu thế Bần chua và một ít ở rừng Đâng tại Đồng Rui và vì thế giá trị sử dụng cũng như bảo tồn còn hạn chế nhưng ngược lại, Cỏ ngạn là loài phân bố tự nhiên trong các sinh cảnh đất ngập nước, thảm cỏ biển, thực sự là loài quý hiếm và có giá trị bảo tồn đáng kể, đồng thời loài này cũng đang bị đe dọa do sinh cảnh bị thu hẹp sau các hoạt động đánh bắt, đặc biệt là quây ao nuôi trồng hải sản trước đây đã làm sinh cảnh của chúng bị suy giảm đáng kể. Đối với các loài động vật, đa số là động vật ở cạn như các loài rắn và thú thì sự xuất hiện tại các sinh cảnh ven biển gần như rất hãn hữu, nhất là đối với các loài thuộc lớp thú do sinh cảnh và nguồn thức ăn bị hạn chế trong khi tác động của con người quá lớn, đặc biệt là săn, bẫy, bắt. Vì thế sự xuất hiện của các loài này hầu như chỉ được ghi nhận theo tài liệu trước đây mà hiện tại có thể đã không còn nữa. Ngược lại, đối với các loài thủy sinh, sự tồn tại của các loài như Cá bống bớp (Bostrichthys sinensis) cấp CR, Cá mòi cờ hoa (Clupanodon thrissa) cấp $\mathrm{EN}$ hay Cá mòi chấm (Konosirus punctatus), Mòi cờ mõm tròn (Nematalosa nasus) cùng cấp VU cho thấy giá trị bảo tồn không nhỏ của các sinh cảnh thủy sinh. Ngoài ra, với sự phong phú về nguồn thức ăn thì các loài chim như Cốc đế (Phalacrocorax carbo), Cò mỏ thìa (Platalea minor) cấp EN hay Bói cá lớn (Ceyx lugubris), Cò lạo ấn độ (Mycteria leucocephala) cấp VU cũng góp phần quan trọng và thực tế cho giá trị bảo tồn của HST vùng ven biển Đông Bắc. Cò mỏ thìa xuất hiện vào mùa đông, gặp ở các bãi triều ngập nước như khu vực cửa sông, các bãi gian triều và vùng cỏ ngập nước, ruộng lúa nước. 
Đối với các loài cần phải bảo tồn theo IUCN, hầu hết đều là những loài thủy sinh và thực sự có giá trị như Sam ba gai đuôi, Cá lành canh đỏ, Cá thu chấm, Cỏ nàn. Tuy nhiên, những loài như Cá diếc mắt đỏ thực sự là loài phân bố rộng ở Việt Nam trong các sinh cảnh nước ngọt và nước lợ, nhưng chưa phải đối tượng cần bảo tồn tại khu vực. Các loài rắn Cạp nia, Lục và Cầy mực được cho là có vùng phân bố tại khu vực nhưng do mức độ săn lùng cao nên hầu như hiện tại không còn tìm thấy tại các sinh cảnh của khu vực nghiên cứu, đồng thời chúng đều là những loài ở cạn nên giá trị bảo tồn đối với các khu vực đất ngập nước có thể sẽ không được đánh giá cao. Ngoài ra, các loài gần nguy cấp (NT) thực sự chưa có nhiều giá trị bảo tồn ở khu vực mặc dù một số loài có giá trị kinh tế và một số loài có vùng phân bố hẹp hoặc là chim di cư. Tương tự như vậy, các loài được IUCN đánh giá ở cấp LR, LC hoặc DD có thể không đóng vai trò quan trọng trong giá trị bảo tồn chung của HST nhưng phần lớn các loài thủy sinh trong số đó là những loài có giá trị kinh tế đáng kể, cần được quan tâm khai thác hợp lý.

Bên cạnh những loài đã được ghi nhận trong SĐVN (2007) và IUCN (2020), HST khu vực ven biển Đông Bắc còn có mộ số loài đáng chú ý, có giá trị nhất định đối với công tác bảo tồn, đó là các loài đặc hữu như Hếp hải nam (Scaevola taccada) là loài đặc hữu chỉ phân bố trong khu vực này và đến đảo Hải Nam (Trung Quốc); Nhài hạ long (Jasminum alongense) loài đặc hữu hẹp mới được ghi nhận ở Quảng Ninh (Vịnh Hạ Long, Hòn Gai).

Chùm gửi tiên yên (Loranthus tienyenensis) là loài đặc hữu ghi nhận duy nhất ở khu vực Tiên Yên (Quảng Ninh); Chuồn chồn ngô (Nannophya pygmaea) là loài chuồn chuồn nhỏ nhất thế giới, phân bố ở các khu vực có đồng cỏ năn ven biển Quảng Ninh, đây là điểm ghi nhận thứ 2 tại Việt Nam (điểm 1 là huyện đảo Phú Quốc), loài này rõ ràng là loài có vùng phân bố hẹp nên mặc dù chưa được đánh giá mức độ nguy cấp nhưng cũng là đối tượng cần ưu tiên bảo tồn.

\section{Kết luận}

Kết quả điều tra thực địa đã xác định các HST ĐNN ven biển Đông Bắc Việt Nam gồm Rừng ngập mặn, Vùng cửa sông và Trảng cỏ ngập nước trong đó, rừng ngập mặn gồm các trạng thái khác nhau theo loạt diễn thế từ tiên phong là Mắm và Sú cong đến các ưu hợp phức tạp hơn và trạng thái tốt nhất hiện nay là sự ưu thế của Đâng, Đước, Bần chua. HST Rừng ngập mặn cũng gồm các trạng thái khác nhau do khác nhau về nguồn gốc hình thành, trong đó, các trạng thái tự nhiên chủ yếu tìm thấy ở khu vực Quảng Ninh và trạng thái rừng trồng là đặc trưng bên phía Hải Phòng. HST khu vực cửa sông cũng đóng vai trò rât quan trọng với các quần xã thực vật ven bờ và sinh cảnh vẫn chịu sự chi phối của thủy triều. Thảm cỏ biển là HST thủy sinh hoàn toàn nhưng vẫn chịu ảnh hưởng của thủy triều và phân bố gần như xen kẽ với HST rừng ngập mặn nên có mức độ đa dạng đáng kể và có vai trò hết sức quan trọng trong bảo tồn và phục hồi đa dạng sinh học của khu vực, đặc biệt thảm cỏ biển là bãi để của nhiều loài hải sản quý hiếm, có giá trị kinh tế cao. HST trảng cỏ ngập nước có mức độ đa dạng sinh học thấp hơn do mức độ ảnh hưởng của thủy triều không nhiều và cơ bản đã bị cô lập bởi các hoạt động nhân tác.

Kểt quả khảo sát về thành phần loài, bằng một hệ thống thống nhất phân chia sinh giới theo các cấp độ từ giới, ngành, lớp, bộ, họ và chi đã xác định được các chỉ số đa dạng loài của các hệ sinh thái trên, trong đó, rừng ngập mặn có 1379 loài, vùng cửa sông có 1024 loài, thảm có biển có 976 loài và thấp hơn hẳn là trảng cỏ ngập nước (433 loài). Cả vùng cửa sông và các khu vực rừng ngập mặn đều là những sinh cảnh rất quan trọng duy trì mức độ đa dạng sinh học chung cho vùng biển Đông Bắc Việt Nam cũng như các nguồn lợi thủy hải sản khác. Hiện đã ghi nhận 26 loài quý hiếm theo Sách Đỏ Việt Nam (2007) và 17 loài nguy cấp theo IUCN (2020) cùng với gần 400 loài khác đã được ghi nhận theo IUCN nhưng chưa ở mức độ bị đe dọa. Ngoài ra, có 4 loài cũng được đánh giá là đặc hữu có mặt trong các sinh cảnh ĐNN ven biển Đông Bắc. 
Mặc dù vậy, các kết quả trên chi ra rằng các HST ĐNN ven biển Đông Bắc vẫn đang trong quá trình diễn thế hướng tới trạng thái đỉnh cực, do đó, cần phải có những kế hoạch bảo tồn và sử dụng hợp lý các nguồn lợi thủy hải sản cụ thể cho từng HST nói riêng và cho toàn bộ khu vực ĐNN ven biển Đông Bắc nói chung, điều đó cần thiết có sự chung tay của các cấp ngành cũng như những cư dân trực tiếp sử dụng và hưởng lợi từ các HST này.

Đóng góp của tác giả: Xây dựng ý tưởng nghiên cứu: N.M.H., V.A.T., T.T.T.V., P.H.H.; Lựa chọn phương pháp nghiên cứu: V.A.T., T.T.T.V., N.M.H.; Xử lý và phân tích số liệu: V.A.T., T.T.T.V.; Xử lý số liệu và lập bản đồ: N.M.H., N.V.H., N.T.N., H.B., D.T.H.Y., Đ.N.T.; Viết bản thảo bài báo: V.A.T, N.M.H., Chỉnh sửa bài báo: V.A.T., N.M.H., T.T.T.V.

Lời cảm ơn: Nhóm tác giả của bài báo xin gửi lời cảm ơn nhiệm vụ "Đánh giá đa dạng sinh học và lượng giá kinh tế tài nguyên các hệ sinh thái đất ngập nước ven biển vùng Đông Bắc Việt Nam phục vụ phát triển bền vững", mã số UQSNMT.02/20-21 thuộc Chương trình Sự nghiệp môi trường: của Viện Hàn lâm Khoa học và Công nghệ Việt Nam đã cung cấp nguồn số liệu cũng như một phần kết quả nghiên cứu phục vụ cho bài báo này.

Lời cam đoan: Tập thể tác giả cam đoan bài báo này là công trình nghiên cứu của tập thể tác giả, chưa được công bố ở đâu, không được sao chép từ những nghiên cứu trước đây; không có sự tranh chấp lợi ích trong nhóm tác giả.

\section{Tài liệu tham khảo}

1. Umali R.M. UNDP/UNESCO. Mangrove of Asia and the Pacific: Status and mangement. 1987, pp.538.

2. Thanh, Đ.N. Sinh vật và Sinh thái biển. Chuyên khảo Biển Đông. Nhà xuất bản Khoa học tự nhiên và Công nghệ, Hà Nội, 2009, 4, tr. 454.

3. Sở Tài nguyên và Môi trường tỉnh Quảng Ninh. Báo cáo tổng hợp Thành lập Khu bảo tồn đất ngập nước Đồng Rui - Tiên Yên, tỉnh Quảng Ninh. Hà Nội, 2017.

4. Thạnh, T.Đ. Thiên nhiên và Môi trường vùng bờ Hải Phòng. Nhà xuất bản Khoa học tự nhiên và Công nghệ, Hà Nội, 2015, tr. 310.

5. Huyền, N.T.M.; Hà, T.M.; Trang, C.T.; Nhơn, Đ.H.; Thư, P.T. Các giá trị sử dụng được mang lại từ hệ sinh thái rừng ngập mặn Tiên Lãng, Hải Phòng. Tạp chí Khoa học và Công nghệ biển 2011, T11(1), 57-72.

6. Thảo, N.V.; Bào, Đ.V.; Lân, T.Đ. Biến động phân bố các hệ sinh thái tiêu biểu vùng bờ biển Quảng Ninh. Tạp chí Khoa học và Công nghệ Biển, 2013, 13(4), 349-435.

7. Hồng, P.N. Sinh thái thảm thực vật rừng ngập mặn Việt Nam. Luận án Tiến sĩ khoa học Sinh học, Trường Đại học Sư phạm Hà Nội 1, Hà Nội, 1991.

8. Aragones, L.V.; Bantayan, N.C.; de Guzman, A.B.; Siringan, F.P.; Uy, W.H.; Maria, Y.Y.S.; Amor, A.K.S.; Ignacio, C.S.; Visco, E.S.; Esguerra, S.S. Coastal and Marine Biodiversity Assessment and Monitoring Manual: How-to Guidelines. Biodiversity Management Bureau and the Deutsche Gesellschaft für Internationale Zusammenarbeit (GIZ) GmbH, 2016, pp. 90.

9. Hộ, P.H. Cây cỏ Việt Nam, Tập 1-3. Nhà xuất bản Trẻ, Tp. Hồ Chí Minh, 19992001.

10. Thìn, N.N. Các phương pháp nghiên cứu thực vật. Nhà xuất bản Đại học Quốc gia Hà Nội, Hà Nội. 2004, tr.165.

11. Huỳnh, Đ.H. Động vật chí Việt Nam. Nhà xuất bản Khoa học tự nhiên, Hà Nội. 2001-2017.

12. Tiến, Đ.V. Khảo sát thú ở miền Bắc Việt Nam. Nhà xuất bản Khoa học và Kỹ thuật, Hà Nội. 1985, tr. 329.

13. Craik, R.C.; Minh, L.Q. Birds of Vietnam. Lynx and Birdlife International Field Guides. Lynx Editions, Barcelona. 2018, pp. 400.

14. Hùng, L.M. Giới thiệu một số loài Chim Việt Nam. Nhà xuất bản Khoa học Tự nhiên và Công nghệ. 2012, tr. 585 . 
15. Sáng, N.V.; Cúc, H.T.; Trường, N.Q. Danh lục ếch nhái và bò sát Việt Nam. Nhà xuất bản Nông nghiệp, Hà Nội. 2005, tr. 180.

16. Chung, B.Đ. Nguồn lợi cá biển Việt Nam. Chuyên khảo biển Việt Nam. Tập 4. 1994.

17. Bộ Khoa học và Công nghệ, Viện Khoa học và Công nghệ Việt Nam. Sách Đỏ Việt Nam. Phần I - Động vật. Nhà xuất bản Khoa học tự nhiên và Công nghệ, Hà Nội. 2007, tr. 603.

18. Bộ Khoa học và Công nghệ, Viện Khoa học và Công nghệ Việt Nam. Sách Đỏ Việt Nam. Phần II - Thực vật. Nhà xuất bản Khoa học tự nhiên và Công nghệ, Hà Nội. 2007, tr. 691.

19. Tiến, N.V. Nguồn lợi thảm cỏ biển Việt Nam. Nhà xuất bản Khoa học và Kỹ thuật, Hà Nội. 2013, tr. 436.

20. Dữ liệu về các loài cá: https://www.fishbase.de/ accessed date: 1/10/2021

21. Dữ liệu về động vật biển: https://www.marinespecies.org/ accessed date: 1/10/2021

22. Dữ liệu về tảo: https://www.algaebase.org/ accessed date: 1/10/2021

23. Danh mục thực vật bậc cao: http://www.theplantlist.org/ accessed date: 1/10/2021

24. The IUCN Red List of Threatened Species: https://www.iucnredlist.org/ accessed date: $1 / 10 / 2021$.

\title{
Results of Biodiversity research on Wetland Ecosystem at the Northeast Coast region of Vietnam
}

\author{
Nguyen Manh Ha ${ }^{1}, \mathrm{Vu}$ Anh Tai ${ }^{{ }^{*}}$, Tran Thi Thuy Van ${ }^{1}$, Pham Hoang Hai ${ }^{1}$, Duong Thi \\ Hong Yen ${ }^{1}$, Nguyen Thu Nhung ${ }^{1}$, Hoang Bac ${ }^{1}$, Nguyen Van Hong ${ }^{1}$, Do Ngoc Thuc ${ }^{2}$ \\ ${ }^{1}$ Institute of Geography, Vietnam Academy of Science and Technology; \\ haig2007@gmail.com; tranthithuyvan@ig.vast.vn; phhoanghai@yahoo.com; \\ duongthihongyen@gmail.com; nthunhung@gmail.com; hoanhbaok2@yahoo.com; \\ nguyenhong.ig@gmail.com \\ 2 Institute of Marine Geology and Geophysic, Vietnam Academy of Science and \\ Technology; dothuc.vn@gmail.com
}

\begin{abstract}
In this paper, the wetland ecosystems on at the northeast coast region of Vietnam have been descripted within 4 main ones as mangrove forests, esturines, sea grass bed and wet grassland. The ecological succession of wetland communities is identified, whereby, the priory community is white mangrove or black mangrove that often grows in pure population on liquid mud at the outermost end of the biome, going deeper, it is Kandelia candel mixed with Bruguiera gymnorrhiza and the central is abundant of red mangroves while mangrove apple was found on the highest grounds. At species diversity, the richest ecosystem is mangrove forest with 1379 species, estuarine region has 1024 species, seagrass bed has 976 species and wet grassland has 433 species. The valued and threatened species was mentioned in this paper with 26 ones recorded in Vietnam Red Data Book (2007) and 17 ones listed in IUCN Red List Category (2020). Finally, the result show that the ecosystem in the northeast coastal region has been in ecological succession toward the climax, so it is necessary to have plans for conservation and rational use of specific aquatic resources for each ecosystem in particular and for the entire Northeast coastal wetland in general.
\end{abstract}

Keywords: Ecosystems; Biodiversity; Wetland; Mangrove forest; Northeast coastal. 